\title{
Tingkat partisipasi Masyarakat dalam Pengembangan Wisata Alam di Curug Bidadari Sentul, Bogor.
}

\author{
Intan Rachmawati, Riza Firmansyah \\ Fakultas Pariwisata-Universitas Pancasila \\ e-mail: tourism@univpancasila.ac.id
}

\begin{abstract}
Community participation is the participation of a person in a social group to take part in the activities of his community, outside his own work or profession. This study aims to see the characteristics of society, the level of community participation in the development of nature tourism in Curug Bidadari and the relationship of characteristics and levels of community participation. Methods of data collection conducted by distributing questionnaires, interviews, observation and literature study. The data obtained are then analyzed and presented quantitatively and supported by qualitative data, where the results will be expressed in percentage numbers. Data analysis techniques used in this study is to test the validity, reliability test and use the method of spearman rank analysis. The result of research shows that the characteristics of the society are seen in terms of age dominated by the age of 30-40 years as much as 40\%, gender in female domination as much as 52\%, education in dominance of high school graduates as much as $34 \%$ and work in entrepreneurial dominance by $44 \%$. The level of community participation around Curug Bidadari falls into the moderate category of $85 \%$ and the relationship of the community participation variable to the characteristics of society as a whole has a very weak relationship. The development of public participation tourism is still less than the maximum due to lack of public understanding of the importance of participation in tourism development activities.
\end{abstract}

Keyword: Community participation, Characteristics of society.

\section{PENDAHULUAN}

Pariwisata merupakan salah satu industri yang paling pesat perkembangannya, sudah lebih dari 1 Milyar orang melakukan perjalanan pada tahun 2015 dan orang yang melakukan perjalanan semakin meningkat setiap tahunnya (UNWTO,2015). Pariwisata mampu menghasilkan penyediaan lapangan kerja, menstimulasi berbagai sektor produksi, serta memberikan kontribusi secara langsung bagi kemajuankemajuan perbaikan infrastruktur serta mendorong pelaksanaan program kebersihan dan kesehatan, proyek sasana budaya, pelestarian lingkungan hidup dan sebagainya yang dapat memberikan keuntungan baik kepada masyarakat lokal maupun wisatawan yang datang (Pendit, 1990).
Partisipasi masyarakat secara sederhana diartikan dengan keikutsertaan masyarakat dalam suatu kegiatan baik itu pada tahap persiapan, perencanaan, design, pelaksanaan maupun monitoring dan evaluasi. Keikutsertaan masyarakat ini dapat dibagi atas beberapa tingkatan sesuai kedalaman keterlibatannya. Keterlibatan atau peran serta masyarakat secara tidak langsung dalam pembangunan sangat diperlukan, bahkan merupakan faktor yang penting. Partisipasi masyarakat dalam pembangunan dapat dilakukan mulai dari tahap perencanaan, pelaksanaan, pengawasan, pemeliharaan dan pelestariannya. Curug Bidadari Sentul sendiri berada di Desa Bojong Koneng Sentul Bogor Jawa barat, sehingga tidak salah jika salah satu Air Terjun di Bogor Jawa Barat yang sangat indah ini terlebih dahulu populer dengan nama Curug 
Bojong Koneng. Air terjun ini berada di atas tanah milik Perhutani dan sebagian lahan masyarakat, sehingga air terjun ini di kelola sepenuhnya oleh masyarakat. Namun, setelah lahan masyarakat dibeli oleh pihak swasta, maka Curug Bojong Koneng ini dikelola langsung oleh pihak pengembang yakni Sentul Paradise Park dan bekerjasama dengan pihak Perhutani.

Sedangkan untuk menjadikan sebuah pariwisata yang berkelanjutan, secara sederhana dapat didefinisikan sebagai pariwisata yang memperhitungkan penuh aspek ekonomi, sosial dan lingkungan saat ini dan masa depan untuk memenuhi kebutuhan wisatawan, industri dan masyarakat setempat. Untuk menjamin berkelanjutan jangka panjang, maka harus dibangun dengan baik terutama pengembangan pariwisata berkelanjutan yang sangat memerlukan partisipasi dari para stake holder terkait khususnya partisipasi dari masyarakat lokal.

Atas dasar pemikiran tersebut, penelitian ini di fokuskan pada tingkat partisipasi masyarakat dalam pengembangan wisata alam di Curug Bidadari Sentul, Bogor. sehingga peneliti dapat melihat atau mengetahui tingkat partisipasi masyarakat berdasarkan Tipologi Partisipasi Masyarakat menurut Teori Pretty (1995). Dan sebesar apa partisipasi masyarakat akan pengembangan sebuah wisata alam yang ada di daerah setempat. Selain itu, juga diharapkan dapat memberikan informasi kepada pihak-pihak terkait.

\section{METODE PENELITIAN}

Penelitian dilakukan di Curug Bidadari yang berada di Desa Bojong Koneng, Kecamatan Babakan Madang, Kabupaten Bogor. Lokasi dipilih secara sengaja dengan pertimbangan Kecamatan
Babakan Madang merupakan salah satu daerah yang kunjungan wisatawannya selalu meningkat di setiap tahunnya dan menjadi salah satu daerah di Kabupaten Bogor yang sedang mengembangkan kegiatan pariwisata. Penelitian ini dilakukan selama 3 bulan, dari bulan Mei hingga bulan Juli.

Jenis penelitian ini menggunakan metode analisis data Kuantitatif dan dukungan data Kualitatif untuk menilai tingkat partisipasi masyarakat. Penelitian ini diharapkan mendapatkan informasiinformasi empiris yang berhubungan erat dengan gambaran aktual pariwisata di Curug Bidadari Sentul Bogor.

Sumber data dalam penelitian ini adalah responden dan informan. Responden adalah orang-orang yang merespon atau menjawab pertanyaan ataupun pernyataan baik tertulis maupun lisan. Dalam penelitian ini menggunakan teknik penentuan informan dengan teknik purposive sampling. Purposive Sampling adalah teknik penentuan sampel dengan pertimbangan tertentu (Sugiyono, 2012). Dan untuk penentuan responden menggunakan teknik simple random sampling. Menurut Sugiyono (2012) simple random sampling merupakan teknik pengambilan sampel anggota populasi secara acak tanpa memperhatikan strata yang ada dalam populasi itu.

Analisis statistik deskriptif merupakan suatu teknik analisis yang menggambarkan data-data yang telah terkumpul secara deskriptif sehingga tercipta sebuah kesimpulan yang bersifat umum. Hal tersebut berarti analisis statistik deskriptif mengakumulasikan data secara deskriptif tanpa menguraikan hubungan, menguji hipotesis, bahkan melakukan penarikan kesimpulan (Muhson 2006). Analisis statistik deskriptif yang digunakan berupa penyajian data dalam bentuk tabel sehingga diketahui kecenderungan hasil 
temuan penelitian yang masuk dalam kategori rendah, sedang, atau tinggi.

\section{Tingkat Partisipasi Masyarakat}

Proses mengubah data berskala ordinal menjadi data berskala interval, ada beberapa tahapan yang harus dilakukan, yaitu:

1. Menghitung Frekuensi, banyaknya tanggapan responden dalam memilih skala ordinal $1 \mathrm{~s} / \mathrm{d} 3$.

2. Menghitung Proporsi, membagi setiap frekuensi dengan jumlah responden.

3. Menghitung Proporsi Kumulatif, menjumlahkan proporsi cara berurutan untuk setiap nilai dan Transformasi dengan Aplikasi EXCEL, nilai skala dengan rumus: $\mathrm{y}=((\mathrm{JO}-\mathrm{Nmin}) /(\mathrm{Nmax}-$ Nmin) $) * 100$.

\section{Analisis Skoring}

Pengukuran partisipasi dikelompokkan dalam tiga kategori skor, yaitu:

a. Rendah : Jika skor jawaban responden berada di selang bawah.

b. Sedang : Jika skor jawaban responden berada di selang tengah.

c. Tinggi : Jika skor jawaban responden berada di selang atas

Penentuan selang dilakukan dengan cara sebagai berikut:

$$
\mathrm{ST}=\frac{(\text { skor minimum }+\mathrm{SK} \max -\mathrm{SK} \min )}{2} \pm \mathrm{SD}
$$

Keterangan:

$\mathrm{SA}=$ nilai skor lebih besar dari ST sampai dengan SK max

$\mathrm{SB}=$ nilai skor lebih kecil dari ST sampai dengan SK min

Keterangan:

ST : Selang tengah

SK min : Penjumlahan skor terendah dari semua item jawaban

SK max : Penjumlahan skor tertinggi dari semua item jawaban
SA : Selang atas

SB : Selang bawah

SD : Standar deviasi/simpangan baku = $\sqrt{ } 2$

\begin{tabular}{|c|c|}
\hline \multicolumn{2}{|c|}{ Selang Skor } \\
\hline Katagori & Partisipasi \\
\hline Atas & $>68,88$ \\
\hline Tengah & 36,74 \\
& $(23,98-68,88)$ \\
\hline Bawah & $<23,98$ \\
\hline
\end{tabular}

\section{Analisis Deskriptif Kualitatif}

Penilaian persepsi masyarakat dilakukan dengan menggunakan skoring skala likert sehingga setiap pertanyaan memiliki skor 1 sampai 5. Setiap indikator dari aspek yang dikaji memiliki nilai rataan, dan pengolahan data dilakukan dalam bentuk tabulasi, kemudian dianalisis secara deskriptif kualitatif untuk menggambarkan persepsi masyarakat. Persepsi masyarakat terhadap pengembangan wisata yaitu:

a. Partisipasi tinggi: apabila mereka memahami dengan baik bahwa partisipasi masyarakat sangat penting dalam kegiatan pariwisata dan mengharapkan agar masyarakat lokal dapat menikmati hasil dari kegiatan pariwisata dan dapat mengelola secara berkelanjutan.

b. Partisipasi sedang: apabila responden menyadari partisipasi masyarakat lokal sangat penting dalam kegiatan parisiwata, namun tidak memahami bagaimana cara mengelola sumberdaya tersebut agar tersedia secara berkelanjutan.

c. Partisipasi rendah: apabila responden tidak ikut berkontribusi dan mengerti peranan masyarakat lokal terhadap kegiatan pariwisata yang ada di sekitarnya.

Analisis rank korelasi Spearman 
Harun Al Rasyid (1996) dalam Citra Dewi Nugrahenny (2016) menyatakan bahwa Analisis ini digunakan untuk melihat ada tidaknya hubungan antara variabel Karakteristik Masyarakat dan partisipasi masyarakat. Uji korelasi "Rank Spearman" dipilih dalam penelitian dengan pertimbangan bahwa kedua variabel penelitian tingkat pengukurannya adalah ordinal. Uji korelasi dilakukan dengan menggunakan software SPSS ver 16.0. Keeratan hubungan diinterpretasikan dengan menggunakan aturan Guilford (Guilford's Emprirical Rule) sebagai berikut:

- $0 \rightarrow<0.2$ : Slight correlation; almost negligible relationship

- $\geq 0.2 \rightarrow<0.4$ : Small correlation: low relationship

- $\geq 0.4 \rightarrow<0.7$ : Moderate correlation; substantial relationship

- $\geq 0.7 \rightarrow<0.9$ : High correlation; dependable relationship

- $\geq 0.9 \rightarrow<1.0$ : Very high correlation; very dependable Relationship.

\section{Uji Validitas}

(Sugiyono,2006) Uji Validitas adalah suatu langkah pengujian yang dilakukan terhadap isi (content) dari suatu instrumen, dengan tujuan untuk mengukur ketepatan instrumen yang digunakan dalam suatu penelitian. Pendekatan yang dilakukan adalah menghubungkan suatu construct. Dimana suatu indikator dipandang "valid" sepanjang sesuai dengan telaah. Dasar pengambilan keputusan uji validitas adalah sebagai berikut:

1. Jika p-value < alpha 0,05 maka item pernyataan valid

2. Jika p-value > alpha 0,05 maka item pernyataan tidak valid

\section{Uji Reliabilitas}

(Sugiyono, 2006) Uji Reliabilitas merupakan suatu pengujian terhadap konsistensi, akurasi prediktabilitas alat ukur. Reliabilitas adalah istilah yang dipakai untuk menunjukan sejauh mana hasil pengukuran relative konsisten apabila pengukuran diulang dua kali atau lebih. Reliabilitas diuji dengan menggunakan item-item consistency reliability yang melihat cronbach's coficien alpha sebagai koofisien dari reliabilitas. Suatu instrumen dapat dianggap reliable jika memiliki Koofisien (a) sebesar 0,6 atau lebih.

1. Jika koofisien alpha (a) pengujian lebih besar > 0,6 maka pernyataan dalam kuesioner layak digunakan (reliable)

2. Jika koofisien alpha (a) pengujian lebih kecil < 0,6 maka pernyataan dalam kuesioner tidak layak digunakan (tidak reliable)

\section{HASIL DAN PEMBAHASAN}

Kabupaten Bogor adalah sebuah Kabupaten di Provinsi Jawa Barat, Indonesia. Kabupaten Bogor berbatasan dengan Kabupaten Tangerang, Kota Tanggerang Selatan (Banten), Kota Depok, Kota Bekasi, dan Kabupaten Bekasi . Kabupaten Bogor terdiri atas 40 kecamatan, yang dibagi atas sejumlah desa dan kelurahan. Pusat pemerintahan Kabupaten Bogor terletak di Kecamatan Cibinong, yang berada di sebelah utara Kota Bogor.

Curug Bidadari Sentul Paradise Park berada di Desa Bojong Koneng Sentul Bogor Jawa Barat. Sehingga tidak salah jika salah satu air terjun di Bogor Jawa Barat yang sangat indah ini terlebih dahulu populer dengan Curug Bojong Koneng. Sebelum tahun 2011, Curug Bidadari berada di tanah milik Perhutani dan beberapa tanah milik masyarakat, sehingga Curug Bidadari di kelola langsung oleh masyarakat sekitar. Namun, pada tahun 2011 tanah milik masyarakat tersebut dibeli oleh pihak swasta dan setelah lokasi wisata alam di Bogor ini dikelola oleh pengembang swasta yakni Sentul Paradise Park, nama Curug Bojong Koneng pun 
dirubah menjadi Curug Bidadari, dan menjadi salah satu tempat wisata di Sentul Bogor yang semakin menarik.

Curug Bidadari Sentul merupakan salah satu destinasi unggulan di Sentul Paradise Park. Desain dari wisata ini memang tidak begitu natural, karena sudah ada wahana buatan seperti kolam renang dan lain lain. Meskipun begitu, air yang digunakan sangat alami. Sejak pertama kali dipublikasikan, konsep Air terjun Bidadari dibuat modern, dimana selain melihat air terjun, pengunjung dapat bermain air bersama keluarga

Curug Bidadari Sentul Paradise Park adalah lokasi wisata air terjun Bogor yang mempunyai ketinggian hampir 75 meter. Wisatawan yang datang berwisata ke sini, selain bisa menikmati keindahan air terjun yang alami, wisatawan juga akan disuguhi pemandangan alam yang sangat indah, asri dan menyejukan. Setelah direnovasi dan masuk dalam kawasan komersil Sentul Paradise Park, maka kini tempat ini menjadi salah satu tempat rekreasi di Bogor yang terkenal. Berdasarkan cerita masyarakat sekitar yang hingga kini masih diyakini, diantara celah bebatuan besar di Curug Bidadari itu dipercaya sebagai lokasi tempat Jaka Tarub bersembunyi untuk mengintip sejumlah bidadari cantik yang turun dari langit yang hendak mandi di Air Terjun Bojong Koneng ini, maka karena itulah curug di Bogor ini pun diberi nama Curug Bidadari.

\section{Karakteristik Masyarakat}

Karakteristik masyarakat Curug Bidadari Sentul berada di Desa Bojong Koneng yang terdiri terdiri dari 5 Kampung, yaitu: Kp. Cicurug, Kp. Citorek Kidul, Kp. Citanggul, Kp. Dengkleng dan Kp. Citarik yang bertempat tinggal di sekitar Curug Bidadari. Karakteristik masyarakat dalam analisis penelitian ini meliputi Usia, Jenis Kelamin, Pekerjaan dan Pendidikan yang disajikan dalam bentuk gambar sebagai berikut:

\section{a. Usia}

Dari hasil penelitian ini dijelaskan bahwa usia masyarakat di Desa Bojong Koneng yang ikut berpartisipasi dalam pengembangan wisata Curug Bidadari sebagian besar berada pada rentang usia $30-40$ tahun yang sebanyak $40 \%$ persen dan $40-\geq 50$ tahun yaitu sebanyak $38 \%$ persen. Data menyebutkan bahwa usia yang paling banyak ikut serta dalam pengembangan wisata yaitu yang ada pada rentang usia dewasa tua dan dewasa muda. Hal tersebut menunjukan bahwa responden pada usia produktif dalam melakukan pekerjaan dan dapat berkontribusi nyata dalam partisipasi pada pengembangan wisata dikarenakan pada rentang usia produktif masyarakat sangat perlu bekerja guna memenuhi kebutuhan dan keberlangsungan hidup

\section{b. Jenis Kelamin}

Data yang diperoleh dari 100 responden masyarakat menunjukan bahwa jenis kelamin yang ikut berpartisipasi dalam pengembangan wisata di Curug Bidadari Sentul Bogor masih seimbang antara laki-laki dan perempuan. Masyarakat berjenis kelamin laki-laki dengan $48 \%$ persen dan masyarakat berjenis kelamin perempuan dengan $52 \%$ persen. Hal ini menunjukan bahwa keikutsertaan berpartisipasi dalam kegiatan pariwisata sangat diminati oleh setiap masyarakat tidak terkecuali perempuan karena masyarakat menyadari untuk memenuhi kebutuhan dan keberlangsungan hidup masyarakat tersebut. 


\section{c. Pekerjaan}

Masyarakat di sekitar Curug Bidadari Sentul apabila dilihat dari pekerjaannya masih di dominasi oleh kalangan wirausaha dengan presentase sebanyak $44 \%$ persen. Wirausaha masih merupakan pekerjaan utama terutama bagi masyarakat sekitar meliputi usaha bengkel, pengusaha kripik pisang, membuka warung sembako, pengrajin kusen pintu. Menurut masyarakat sekitar, pekerjaan sebagai wirausaha mendapatkan keuntungan yang lebih besar. Untuk pengusaha kripik pisang bahan baku yang tersedia lebih banyak sehingga sebagian masyarakat menjadikannya lahan usaha.

\section{d. Pendidikan Terakhir}

Tingkat pendidikan adalah lama pendidikan formal tertinggi yang pernah ditempuh oleh responden. Sebaran tingkat pendidikan yang ditamatkan oleh responden pada penelitian ini adalah tamat SD, tamat SMP, tamat SMA/SMK dan Sarjana. Pendidikan yang dimiliki oleh anggota masyarakat akan mempengaruhi cara mereka berpikir. Pendidikan dapat diperoleh dari pendidikan formal melalui bangku sekolah dan pendidikan informal misalnya melalui kursus-kursus atau pelatihan. Kebanyakan penduduk di sekitar Curug Bidadari Sentul Bogor lebih tepatnya di Desa Bojong Koneng hanya mengikuti sekolah-sekolah formal saja. Hal ini dikarenakan sekolah formal lebih banyak diminati masyarakat daripada sekolah informal. Karena menurut masyarakat sekolah formal lebih menjanjikan untuk mendapatkan pekerjaan dan lebih dapat memberikan pengetahuan.

\section{Tingkat partisipasi masyarakat dalam pengembangan wisata alam di Curug Bidadari.}

Sardjono (2004) mengemukakan bahwa partisipasi masyarakat merupakan suatu proses dimana masyarakat dilibatkan pada setiap tahap situasi yang berpengaruh terhadap kehidupan mereka. Partisipasi masyarakat yang dikaji dalam penelitian ini berkaitan dengan keikutsertaan masyarakat dalam upaya pengembangan wisata alam di Curug Bidadari Sentul Bogor.

Hasil pengukuran tingkat partisipasi masyarakat sekitar Curug Bidadari Sentul menunjukkan bahwa sebagian besar masyarakat memiliki partisipasi dalam pengembangan wisata alam yang termasuk dalam kategori tinggi sebesar $11 \%$ dan sedang sebesar $85 \%$ serta rendah sebesar $4 \%$. Dengan tingkat partisipasi masyarakat yang termasuk dalam kategori sedang, maka dapat disimpulkan bahwa sebagian masyarakat masih berperan serta terhadap Curug Bidadari. Karena pengembangan Curug Bidadari penting bagi kehidupan masyarakat salah satunya adalah dari aspek ekonomi. Aspek ekonomi tersebut dapat terlihat dari masyarakat yang terlibat terhadap pengembangan wisata alam Curug Bidadari untuk memenuhi kebutuhan hidup sehari-hari atau mencari penghasilan tambahan.

Tingkat partisipasi masyarakat yang tergolong rendah sebesar $4 \%$ menunjukkan bahwa masyarakat kurang aktif dalam mengikuti kegiatan pengelolaan, namun masih peduli dengan menjaga kebersihan dan keamanan Curug Bidadari Sentul, Bogor. 


\begin{tabular}{|c|c|c|c|c|}
\hline \multirow{2}{*}{ No } & \multirow{2}{*}{ Kategori } & \multirow{2}{*}{ Interval } & \multicolumn{2}{|c|}{ Responden } \\
\hline & & & $\mathrm{N}$ & $\%$ \\
\hline 1 & Tinggi & $>68,88$ & 11 & $11 \%$ \\
\hline 2 & Sedang & $\begin{array}{c}23,98-68,88 \\
(36,74)\end{array}$ & 85 & $85 \%$ \\
\hline 3 & Rendah & $<23,98$ & 4 & $4 \%$ \\
\hline
\end{tabular}

Berdasarkan hasil penelitian, tingkat partisipasi masyarakat di Curug Bidadari Sentul berada pada posisi partisipasi insentif. Menurut Pretty (1995), Tingkat partisipasi yang termasuk dalam katagori sedang diartikan dengan Masyarakat berpartisipasi dengan cara berkonsultasi, bertanya, serta dilibatkan dengan diberi upah. Namun masyarakat tidak diikutsertakan dalam dalam proses perencanaan. Masyarakat mengeluarkan pendapat, namun pihak pengelola yang menganalisis hingga memutuskan keputusan secara sepihak. Masyarakat lokal bekerjasama dengan pihak-pihak terkait untuk menentukan prioritas dan pihak tersebut bertanggung jawab sepenuhnya kepada prosesnya tanpa melibatkan masyarakat.

Sehingga masyarakat beranggapan bahwa pengelola masih kurang memberikan penyuluhan tentang pentingnya pengembangan wisata bagi kehidupan masyarakat. Tidak semua masyarakat mengerti akan pengembangan wisata dan manfaat langsung yang akan dirasakan dari adanya pengembangan wisata di Curug Bidadari Sentul.

Tingkat partisipasi katagori sedang ini ada beberapa hal yang perlu diadakannya seperti penyuluhan, pemberdayaan, pelatihan dan pembinaan masyarakat untuk meningkatkan kesadaran dan pengetahuan dari masyarakat, terutama dalam pengembangan wisata di Curug Bidadari Sentul. Sehingga dapat meningkatkan minat dan motivasi masyarakat untuk berkeinginan ikut berpartisipasi dalam pengembangan wisata di Curug Bidadari Sentul.
Masyarakat pernah memiliki konflik dengan pengelola. Konflik yang terjadi terkait beberapa lahan kawasan Curug Bidadari Sentul yang dijadikan sarana untuk menunjang keberlangsungan kegiatan pariwisata di Curug Bidadari. Masyarakat yang mendapatkan dampak akibat dari adanya kegiatan pariwisata akan diberikan kompensasi. Namun dari awal adanya pengembangan wisata masyarakat belum pernah diberikan kompensasi tersebut. Dengan tidak diberikannya kompensasi tersebut sebagian masyarakat bersikap apatis dan tidak memperdulikan adanya pengembangan wisata tersebut. permasalahan ini masih dalam proses penyelesaian yang baik antara masyarakat dengan pihak pengelola.

Dengan tingkat partisipasi masyarakat yang termasuk dalam kategori sedang, maka dapat disimpulkan bahwa masyarakat paham akan pentingnya pengembangan dan pengelolaan wisata tetapi tidak tahu bagaimana cara mengelolanya dengan baik dan benar. Sesuai pernyataan Ngakan (2006), partisipasi dikategorikan sedang apabila responden menyadari pengembangan wisata penting untuk meningkatkan perekonomian, namun tidak memahami bagaimana cara mengelola sumberdaya wisata tersebut agar tersedia secara berkelanjutan.

Berdasarkan hasil wawancara dengan beberapa informan, keberadaan Curug Bidadari dapat menciptakan lapangan pekerjaan dan meningkatkan pendapatan bagi masyarakat. Namun, sebagian masyarakat beranggapan bahwa rencana kegiatan pengelolaan masih belum banyak melibatkan masyarakat, namun masih banyak menguntungkan pihak pengelola saja. Masyarakat juga belum memahami cara mengelola sumberdaya wisata agar lebih menarik wisatawan dan berkelanjutan dan Masyarakat disekitar Curug Bidadari juga masih banyak yang 
belum peduli akan adanya kegiatan wisata yang ada di daerahnya. Untuk meningkatkan partisipasi positif masyarakat, pengelola perlu melibatkan masyarakat dalam berbagai kegiatan pengelolaan, mulai dari tahap perencanaan sampai pelaksanaannya. Sehingga masyarakat juga merasa memiliki dan berkepentingan dengan adanya pengembangan wisata. Masyarakat juga perlu dibekali keahlian agar dapat mengelola sumber daya wisata, misalnya diberikan pelatihan untuk membuat souvenir atau diberikan pelatihan bagaimana cara melayani tamu dengan baik. Sehingga mereka mampu melayani dan memuaskan wisatawan, Maka keberadaan pengembangan wisata dapat dipertahankan. Selain itu juga diberikan pengetahuan agar dapat lebih mengembangkan sumberdaya yang dapat menarik wisatawan untuk berkunjung secara berkelanjutan.

Berdasarkan hasil penelitian, bentuk partisipasi masyarakat di dalam pengembangan wisata alam di Curug Bidadari, antara lain menjaga pintu tiket masuk, menjaga toilet dan membersihkan kantor, menjaga parkir kendaraan, pemandu wisata, pedagang, penyedia homestay. serta menjaga keamanan dan kebersihan kawasan. Bentuk partisipasi masyarakat yang paling banyak adalah pedagang sebesar $35 \%$ dan menjaga keamanan dan kebersihan kawasan sebesar $23 \%$.

Kegiatan partisipasi dalam bentuk pedagang yaitu masyarakat berjualan makanan, baju untuk wisatawan, dan menjual jasa foto keliling. Sedangkan, dalam menjaga keamanan dan kebersihan Curug Bidadari berupa pemeliharaan kawasan dan tidak ada lagi pungutan liar, tidak memberikan akses jalan yang salah terhadap wisatawan, tidak membuang sampah dan membersihkan wilayah Curug Bidadari Sentul, Bogor. Menghindari kegiatan yang bersifat merusak merupakan kegiatan wisata yang dapat menjamin kelestarian wilayah Curug Bidadari karena masih ada pengunjung dan masyarakat yang membuang sampah di kawasan serta melakukan vandalisme.

Melibatkan masyarakat di dalam pengembangan dan pengelolaan wisata juga diperlukan agar pihak-pihak yang terkait dapat bekerjasama dengan baik. Adanya dukungan pemerintah sebagai fasilitator sangat penting untuk mengatasi permasalahan yang terjadi di kawasan terutama kepentingan-kepentingan yang mengelola kawasan.

\section{Hubungan Partisipasi Masyarakat}

dengan Karakteristik Masyarakat.

\begin{tabular}{|l|c|c|c|c|c|}
\hline Corelation & $\begin{array}{l}\text { Partisi } \\
\text { pasi }\end{array}$ & Usia & $\begin{array}{l}\text { Jenis } \\
\text { Kelamin }\end{array}$ & Pendidikan & Pekerjaan \\
\hline Partisipasi & 0 & 0,089 & 0,153 & 0,004 & 0,050 \\
\hline Usia & 0,089 & 0 & $-0,029$ & $-0,198^{*}$ & $-0,267^{* *}$ \\
\hline $\begin{array}{l}\text { Jenis } \\
\text { Kelamin }\end{array}$ & 0,153 & $-0,029$ & 0 & $-0,404^{* *}$ & $-0,165$ \\
\hline Pendidikan & 0,004 & - & - & 0 & $-0,586^{* *}$ \\
& & $\begin{array}{c}0,198 \\
*\end{array}$ & $0,404^{* *}$ & & \\
\hline Pekerjaan & 0,050 & - & $-0,165$ & $-0,586^{* *}$ & 0 \\
& & $\begin{array}{c}0,267 \\
* *\end{array}$ & & & \\
\hline
\end{tabular}

\section{Hipotesa 1}

H1a: Tingkat partisipasi memiliki hubungan terhadap tingkat usia

H1o: Tingkat partisipasi tidak memiliki hubungan terhadap tingkat usia

Usia merupakan jumlah tahun hidup seseorang yang diukur dalam satuan tahun yang dihitung dari hari kelahiran dan dibulatkan kehari ulang tahun terdekat. Klausmeier dalam Hardjono (2000) menyatakan bahwa usia seseorang dapat menunjukkan kematangan emosional, kecermatan, kematangan dan kemampuan berpikir secara empiris. 
Berdasarkan hasil dari uji korelasi rank spearman yang dilakukan terhadap tingkat partisipasi masyarakat dengan usia memiliki nilai koefisien korelasi sebesar 0,089 yang berarti tingkat partisipasi masyarakat memiliki hubungan yang bersangat lemah terhadap tingkat usia, maka dapat disimpulkan tidak terdapat adanya hubungan yang jelas antara tingkat partisipasi masyarakat dengan tingkat usia.

Hal tersebut disebabkan karena kegiatan pengembangan wisata di Curug Bidadari masih sebatas dalam waktu tertentu saja. Kegiatan yang sering dilaksanakan yaitu renovasi infrastruktur Curug Bidadari dan tidak semua anggota bisa ikut serta karena umumnya membutuhkan waktu yang cukup lama. Mayoritas masyarakat yang ikut serta khususnya yang sudah berusia dewasa tua karena memiliki waktu luang yang lebih banyak, dan memiliki kewajiban untuk bekerja dan memenuhi kebutuhan dan keberlangsungan hidupnya. Sehingga mengharuskan untuk ikut berpartisipasi guna meningkatkan pendapatannya. Sedangkan untuk yang berusia muda walaupun memiliki waktu yang cukup banyak mereka telah disibukan dengan kegiatan di sekolah formal, dan mereka belum memiliki kesadaran untuk ikut berpartisipasi dalam pengembangan wisata.

\section{Hipotesa 2}

H1a: Tingkat partisipasi memiliki hubungan terhadap jenis kelamin.

H1o: Tingkat partisipasi tidak memiliki hubungan terhadap jenis kelamin.

Menurut Hungu (2007) Jenis kelamin adalah suatu konsep kultural yang berupaya membuat pembedaan dalam hal peran, perilaku, mentalitas, dan karakteristik emosional antara laki-laki dan perempuan yang berkembang dalam masyarakat.
Berdasarkan hasil dari uji korelasi rank spearman yang dilakukan terhadap tingkat partisipasi masyarakat dengan jenis kelamin memiliki nilai koefisien korelasi sebesar 0,153 yang berarti tingkat pasrtisipasi masyarakat memiliki hubungan yang bersangat lemah terhadap jenis kelamin, maka dapat disimpulkan tidak terdapat adanya hubungan yang jelas antara tingkat partisipasi masyarakat dengan jenis kelamin. Karena untuk masyarakat yang ingin berpartisipasi dalam pengembangan wisata di Curug Bidadari tidak dilihat dari jenis kelamin. Menurut data yang di dapat dari pengelola masyarakat berpartisipasi sesuai dengan kemampuan ataupun proporsinya masing-masing dan pihak pengelola tidak membeda-bedakan masyarakat berdasarkan jenis kelamin. Jenis kelamin masyarakat di Curug Bidadari yang ikut serta dalam partisipasi yaitu perempuan lebih dominan dibandingkan laki-laki, karena perempuan lebih memiliki waktu yang lebih banyak dibandingkan laki-laki sehingga perempuan ingin mendapatkan pendapatan tambahan dengan ikut berpartisipasi dalam pengembangan wisata di daerahnya.

\section{Hipotesa 3}

H1a: Tingkat partisipasi memiliki hubungan terhadap tingkat pendidikan

H1o: Tingkat partisipasi tidak memiliki hubungan terhadap tingkat pendidikan.

Tingkat pendidikan adalah lama pendidikan formal tertinggi yang pernah ditempuh oleh responden. Sebaran tingkat pendidikan yang ditamatkan oleh responden pada penelitian ini adalah tamat SD, tamat SMP, tamat SMA/SMK dan sarjana. Pendidikan yang dimiliki oleh anggota masyarakat akan mempengaruhi cara 
mereka berpikir. Semakin tinggi jenjang pendidikan yang ditempuh seseorang maka akan semakin tinggi pula tingkat partisipasinya dalam mengeluarkan pendapat atau saran.

Berdasarkan hasil dari uji korelasi rank spearman yang dilakukan terhadap tingkat partisipasi dengan pendidikan memiliki nilai koefisien korelasi sebesar 0,004 yang berarti tingkat partisipasi masyarakat memiliki hubungan yang bersangat lemah terhadap pendidikan, maka dapat disimpulkan tidak terdapat adanya hubungan yang jelas antara tingkat partisipasi masyarakat dengan pendidikan.

Hal tersebut didukung dengan hasil pengamatan di lapang, dimana tingkat pendidikan di dominasi masyarakat yang lulus SMA. Dalam pengembangan wisata hanya dijadikan sebagai pelaksana, yaitu penjaga loket pintu masuk Curug Bidadari. Sehingga untuk bagian management dari Curug Bidadari pihak pengelola memilih karyawan yang memiliki tingkat pendidikan $\mathrm{S} 1$ dan berasal dari luar daerah Curug Bidadari. Hal ini kebanyakan masyarakat yang lulusan SMA disekitar Curug Bidadari lebih memilih bekerja ditempat lain daripada ikut bergabung untuk mengembangkan kegiatan pariwisata di daerah tempat tinggalnya. Mereka belum sepenuhnya mengetahui manfaat dari adanya pengembangan pariwisata, serta belum adanya rasa memiliki dan berkepentingan dengan adanya pengembangan wisata di daerahnya.
H1a: Tingkat partisipasi memiliki hubungan terhadap tingkat pekerjaan.

H1o: Tingkat partisipasi tidak memiliki hubungan terhadap tingkat pekerjaan.

Pekerjaan adalah kegiatan yang harus dilakukan orang untuk memenuhi kebutuhannya setiap hari manusia mempunyai kebutuhan pokok yang harus dipenuhi. Berdasarkan hasil uji korelasi rank spearman yang dilakukan terhadap tingkat partisipasi dengan pekerjaan memiliki nilai koefisien korelasi sebesar 0,050. Jadi hubungan pekerjaan dengan tingkat partisipasi masyarakat pada pengembangan wisata memiliki hubungan yang sangat lemah, maka dapat disimpulkan tidak terdapat adanya hubungan yang jelas antara tingkat partisipasi masyarakat dengan pekerjaan.

Hal ini di dukung dengan hasil observasi dilapangan, karena partisipasi masyarakat sekitar Curug Bidadari masih dalam bentuk pelaksanaannya saja. Masyarakat selaku salah satu pemangku kepentingan belum diikutsertakan dari tahap perencanaan, terlebih lagi pada tahap pengambilan keputusan dan juga kebanyakan masyarakat belum menjadikan kegiatan wisata sebagai mata pencaharian pokok. Masyarakat merasa mata pencaharian sebagai wirausaha merupakan pekerjaan yang paling potensial dan masyarakat juga belum banyak merasakan manfaat dari adanya kegiatan wisata di daerahnya. Maka kegiatan wisata hanya dijadikan pekerjaan tambahan untuk kebutuhan masyarakat.

\section{Hipotesa 4}

\section{PENUTUP}




\section{Kesimpulan}

Karakteristik masyarakat yang ikut berpartisipasi dalam pengembangan wisata di Curug Bidadari Sentu, jika di lihat dari segi Usia yaitu lebih banyak yang berkisar Usia 30-40 tahun yang merupakan usia produktif. Jenis Kelamin di dominasi perempuan, lebih banyak yang ikut berpartisipasi dibandingkan laki-laki, karena jenis kelamin yang ikut berpartisipasi tidak dibatasi. Dari segi pendidikan yaitu masyarakat disekitar Curug Bidadari lebih di dominasi oleh lulusan SMA sehinga tidak terlalu sulit untuk terciptanya kondisi pariwisata yang ideal. Dan jika dilihat dari segi pekerjaan masyarakat disekitar Curug Bidadari bekerja sebagai wirausaha. Namun dengan adanya kegiatan pengembangan wisata di daerahnya, masyarakat sekitar Curug Bidadari belum menjadikan kegiatan pariwisata menjadi mata pencaharian pokok.

Tingkat partisipasi masyarakat terhadap pengembangan wisata di Curug Bidadari Sentul termasuk kategori sedang, yang artinya masyarakat berpartisipasi dengan cara berkonsultasi, bertanya, serta dilibatkan dengan diberi upah serta masyarakat tidak diikutsertakan dalam proses perencanaan. Masyarakat mengeluarkan pendapat, namun pihak pengelola yang menganalisis hingga memutuskan keputusan secara sepihak. Bentuk partisipasi masyarakat di dalam pengembangan wisata di Curug Bidadari Sentul, antara lain menjaga toilet dan membersihkan kantor, pemandu wisata, pedagang, penyedia homestay, serta menjaga keamanan dan kebersihan kawasan. Bentuk partisipasi masyarakat yang paling banyak adalah pedagang sebesar $35 \%$ dan menjaga keamanan dan kebersihan kawasan sebesar $23 \%$.

Hubungan partisipasi masyarakat dengan Karakteristik masyarakat memiliki hubungan yang lemah yang dimana menurut aturan Guilford (Guilford's Emprirical Rule) berada pada rentang 0 0.2 atau yang di sebut dengan Slight Corellation. Dari data yang di dapat hubungan dari 2 variabel ini lemah karena masyarakat masih belum peduli dan memiliki kesadaran dengan adanya kegiatan wisata di daerahnya. Karena masyarakat masih kurang mendapatkan penyuluhan mengenai manfaat-manfaat apa saja yang akan di dapat dari kegiatan pariwisata di daerahnya.

\section{Saran}

Berdasarkan hasil penelitian yang dilakukan di Curug Bidadari Sentul Bogor baik dengan melakukan observasi, menyebarkan kuesioner kepada masyarakat dan wawancara kepada pengelola, tokoh masyarakat dan pemerintah yang masing-masing memiliki perannya yang berbeda, maka dapat ditarik beberapa hal yang dapat dijadikan masukan dan saran diantara sebagai berikut:

1. Pihak pemerintah agar lebih meningkatkan penyuluhan dan sosialisasi kepada masyarakat mengenai pengembangan wisata yang sedang dan telah dilakukan agar masyarakat bisa lebih mengetahui dan banyak mengeluarkan pendapat kepada pemerintah

2. Pemerintah dapat lebih memberikan informasi-informasi kepada masyarakat akan manfaat yang akan dirasakan oleh masyarakat dengan adanya pengembangan wisata di daerahnya.

3. Pengelola perlu mengadakan pelatihan-pelatihan agar masyarakat dapat memiliki keahlian dan bisa lebih memberikan partisipasinya dalam pengembangan wisata. 
4. Pengelola perlu mengadakan kegiatan penyuluhan kepada masyarakat mengenai pengembangan wisata di Curug Bidadari untuk meningkatkan pengetahuan masyarakat akan pentingnya manfaat mengembangkan wisata terutama manfaat dari segi ekonomi yang dapat meningkatkan perekonomian masyarakat sekitar.

5. Pengelola bekerjasama dengan masyarakat untuk menjadikan Curug Bidadari Sentul sebagai daya tarik wisata.

6. Masyarakat yang berusia muda dan berpendidikan tinggi didorong untuk menciptakan peluang usaha di Curug Bidadari Sentul.

7. Masyarakat dapat membuat cinderamata dan membuka toko mandiri milik bersama yang menjual produk kreasi masyarakat sebagai variasi kegiatan yang akan ditawarkan kepada wisatawan

\section{DAFTAR PUSTAKA}

Jules n. Pretty. 1995. Participatory

Learning For Sustainable Agriculture. World Development, Vol. 23, No. 8, pp. 1247-1263.

Ngakan. 2006. Ketergantungan, Persepsi dan Partisipasi Masyarakat terhadap Sumberdaya Hayati Hutan Studi Kasus di Dusun Pampli Kabupaten Luwu Utara, Sulawesi Selatan. Center for International Forestry Research.

Nugrahenny, C.D. 2016 . Skripsi: Persepsi Masyarakat terhadap pengelolaan taman wisata alam telogo warno telogo. Bogor. Institut Pertanian Bogor. Fakultas Kehutanan.

Pendit, N.S. 1990. Sebuah Pengantar Perdana, Jakarta: Pradnya Paramita.
Sugiyono. 2013. Metode penelitian pendidikan (pendekatan kuantitatif, kualitatif dan R\&D). Bandung: Alfabeta

Yoeti, O.A. 1997. Perencanaan dan Pengembangan Pariwisata. Jakarta: PT Pradnya Paramita. 